\title{
Taxonomy, distribution and lectotypification of Argyreia longifolia (Convolvulaceae), a poorly known Burmese species from Northeast India
}

\author{
S. Shalini ${ }^{1}$, P. Lakshminarasimhan ${ }^{2}$ and D. Maity ${ }^{3 *}$ \\ ${ }^{1}$ Central National Herbarium, Botanical Survey of India, AJC Bose Indian Botanic Garden, Botanic Garden P.O., \\ Howrah, West Bengal - 711 103, India. \\ ${ }^{2}$ Botanical Survey of India, Western Regional Centre, 7, Koregaon Road, Pune, Maharashtra - 411 001, India. \\ ${ }^{3}$ Department of Botany, Science College, University of Calcutta, 35, Ballygunge Circular Road, Kolkata, West \\ Bengal - 700 019, India. \\ *Email: debmaity@yahoo.com
}

\begin{abstract}
Argyreia longifolia (Collett \& Hemsl.) Raizada, a Burmese species, is confined to Shan hills terai of Maymyo plateau in Burma (now Myanmar). The record of its occurrence in Assam, one of the Northeast Indian states, in earlier reports is without any supporting specimens from this region. Furthermore, there is no detailed description available for this species in any of the existing regional Floras. During the consultation of herbarium specimens of Argyreia at CAL, a specimen collected from Manipur could be traced. As no detailed description has been made till date, the present study attempts to provide a detailed history on the taxonomy and nomenclature of this poorly known species with elaborate description based on both Manipur and Myanmar specimens housed at CAL and DD, illustration and a brief note on the range of its distribution. The micromorphological features of pollen grains and seeds observed with Scanning Electron Microscope are provided in detail along with micrographs. The paper also reports the occurrence of this species for the first time from the state of Manipur. Apart, the name, A. longifolia is lectotypified here in accordance with the International Code of Nomenclature.
\end{abstract}

Keywords: Argyreia, Assam, Manipur, Myanmar, New Report, Typification.

\section{Introduction}

Argyreia Lour., seemingly the most species-rich genus among the tropical Asian Convolvulaceae, is chiefly distributed throughout tropical Asia with 135 species and 5 varieties (Staples \& Traiprem, 2017). In India, till date the genus is represented by 46 taxa (based on the present revisionary study), and it is the second largest genus in Indian Convolvulaceae. A careful scrutiny of literature and consultation of various Indian and foreign herbaria (K, E, BM, G-DC, P) during the present taxonomic revision on Argyreia in India revealed that the genus is majorly confined to southern (especially Western and Eastern Ghats, c. 20 species) and north and northeastern regions (c. 20 species) of the country.

Collett and Hemsley (1890) described Lettsomia longifolia Collett \& Hemsl. based on fruiting specimens collected from 'Shan hills terai' near Pyinyoung in Myanmar at an elevation of about
2000 feet $(610 \mathrm{~m})$. According to them, this species most nearly resembles L. barbata C.B. Clarke but the latter differs in having long linear bracts. Subsequently, Prain (1894) reported it as one of the species addition to Clarke's account on Convolvulaceae for 'The Flora of British India' based on collections of Collett from Shan hills (other than the type collections) and of Dr. King's Collectors from Maymo and Makhoye in Myanmar, and added floral characters to the description. Furthermore, he stated it as "A very distinct species; most nearly allied to L. atropurpurea" (1894: 96).

Clarke (1939) who contributed the taxonomic account of the family Convolvulaceae for Flora of Assam, reported six species of Lettsomia, namely $L$. strigosa Roxb., L. barbigera C.B. Clarke, L. mastersii Prain, L. longifolia Collett \& Hemsl., L. sikkimensis C.B. Clarke and L. rubens C.B. Clarke, of which, Clarke provided detailed account only for $L$. strigosa, and stated that the remaining species 


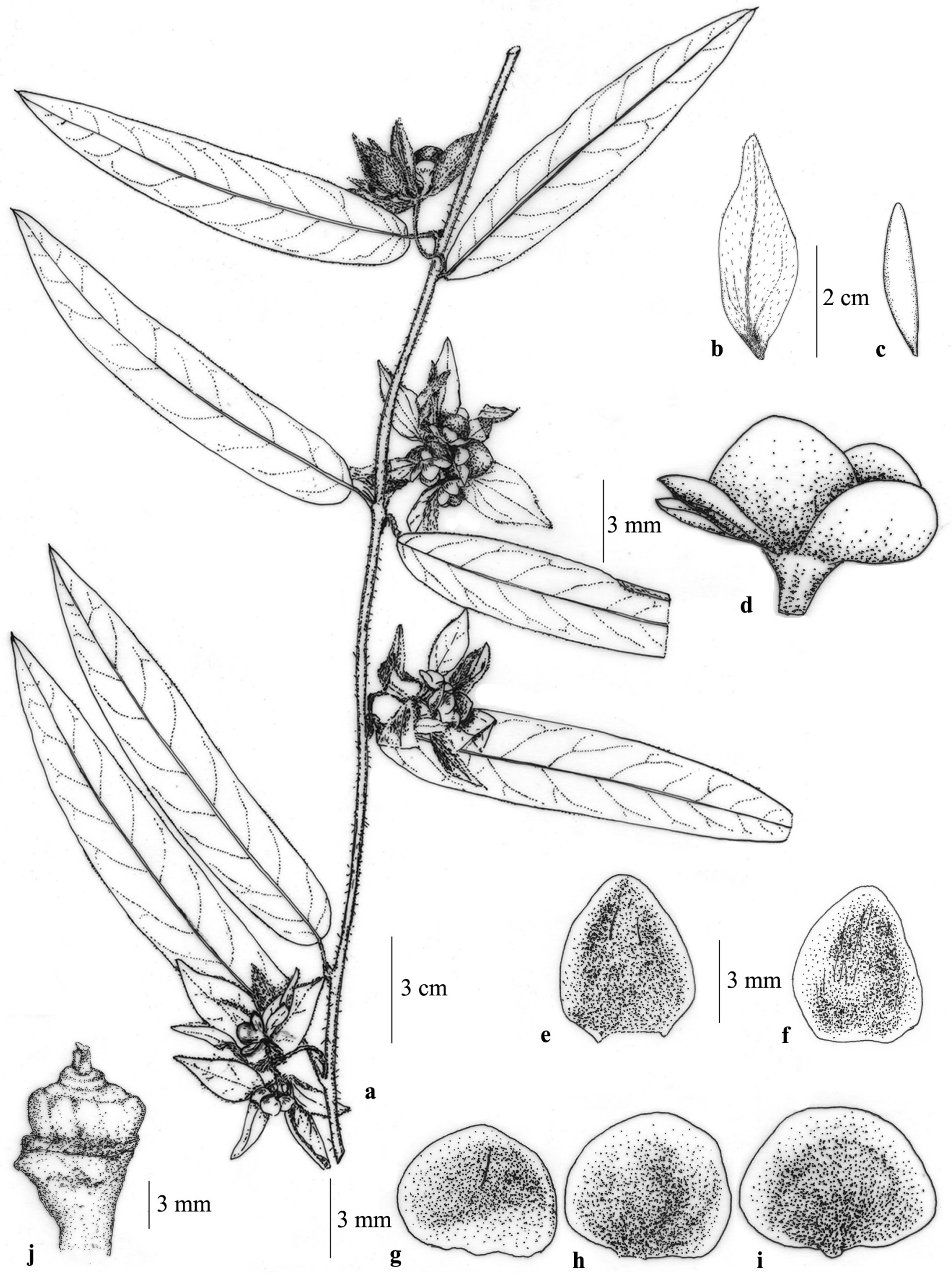

Fig. 1. Argyreia longifolia (Collett \& Hemsl.) Raizada: a. Fruiting-twig; b \& c. Outer and inner bracts; d. Fruiting calyx; e \& f. Outer sepals; g-i. Inner sepals; j. Basal portion of pistil with disk (Illustration by S. Shalini). 
"....are not described in detail as they are not of great importance from forest point of view". Regardless of it, Clarke's inclusion of L. longifolia in the Flora of Assam was the first report of its occurrence from the present political boundary of India, though he did not provide its precise locality and other field data including specimen details.

Raizada (1958) invalidly transferred (not fulfilled the requirements of Art. 33 of the Code) the specific epithet, 'longifolia' from Lettsomia to Argyreia, but he later (Raizada, 1967) validated the name, $A$. longifolia (Collett \& Hemsl.) Raizada. Razi (1959) who enumerated the species and genera of Indian phanerogams that were not included in The Flora of British India (Hooker, 1872-1897) reported this species also on the basis of Collett and Hemsley (1890), Prain (1894) and Clarke (1939). Later, Bennet (1987) and Naithani (1990) also recorded A. longifolia on the basis of the earlier said works. Thereafter, this species has not been included in any of the recent publications till date, including the recently published Checklist of Flora of Meghalaya (Mao et al., 2016).

Hence, during the present revisionary study on the genus Argyreia in India, efforts were taken to trace the representative specimen(s) (if any) of A. longifolia in Indian herbaria, especially at CAL and ASSAM, which resulted in tracing a specimen collected by Meebold from Kaptu in Manipur, India at CAL. Apart, nine more collections from Maymyo and Mandalay regions of Myanmar at CAL and two more from Maymyo at DD were found. However, specimens could not be located in any of the international herbaria (E, BM, G-DC, $\mathrm{P})$, except $\mathrm{K}$ where Collett and Hemsley specimens are housed. This poorly known species is described in detail based on the existing specimens (both Manipur and Myanmar specimens) at CAL and DD. The micromorphological features of pollen grains and seeds observed with Scanning Electron Microscope are provided in detail along with micrographs. Furthermore, a specimen among the existing syntypes has been chosen to serve as the lectotype for the name in accordance with the Article 9.3 of Shenzhen Code (Turland et al., 2018).

\section{Taxonomy}

Argyreia longifolia (Collett \& Hemsl.) Raizada, Indian Forester 93(11): 754. 1967. Lettsomia longifolia Collett \& Hemsl., J. Linn. Soc., Bot. 28: 95. 1890; C.B. Clarke in Kanjilal et al., Fl. Assam 3: 344. 1939.

Lectotype (designated here): Myanmar, Shan hills terai, near Pyinyoung, 2000 feet, November 1887, Collett 120 (K000196046, image!).
Large climbers. Stems hard, grooved, tawnystrigose throughout. Leaves simple, alternate, narrowly oblong-lanceolate, $9.3-16 \times 1.7-2.5 \mathrm{~cm}$, rounded or slightly cuneate at base, entire, hairy at margins, acute or acuminate, short-mucronulate at apex, glabrous above except midrib, sparsely to fairly tawny-strigose beneath; midrib prominent on both surfaces but slightly raised with thick hairs beneath; lateral veins 10-12 pairs, prominent on both surfaces; petioles shorter than leaves, 0.9-1.7 cm long, slender, curved, swollen at base, tawnystrigose. Inflorescence cymose, axillary, fewflowered (2 or 3); peduncles shorter or equaling the petioles, stout, 1-2.5 cm, dense tawny-strigose. Bracts persistent, narrowing towards inner, reddish brown-tinged throughout; outer bracts 2 or 3, leafy, ovate-lanceolate, $3.1-4.8 \times 0.5-1.4 \mathrm{~cm}$, acute, rarely acuminate, densely strigose outside, glabrous inside, prominently veined; inner bracts 2-4, oblong-lanceolate, $2-4 \times 0.2-0.5 \mathrm{~cm}$, glabrous inside, strigose outside. Sepals 5, subequal, much shorter than bracts; outer 2 lanceolate, acute at apex, densely tawny-strigose outside; inner 3 orbicular, margins scarious, strigose only along midrib outside, glabrous inside, reddish brown inside. Corolla infundibular, c. $1 \mathrm{~cm}$ across,

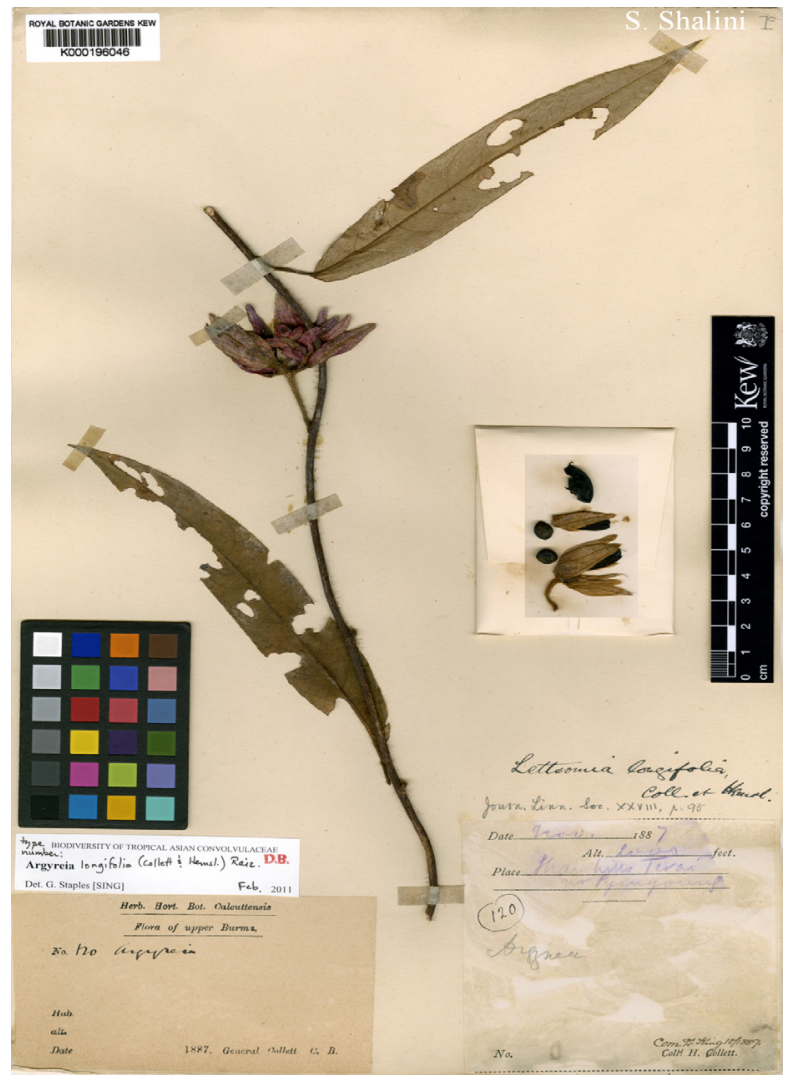

Fig. 2. Lectotype of Argyreia longifolia (Collett \& Hemsl.) Raizada (Lettsomia longifolia Collett \& Hemsl.), Collett 120 (K000196046) (C)The Board of Trustees of the Royal Botanic Gardens, Kew. 
glabrous outside, dark purple, midpetaline bands hairy, slightly lobed; tube c. $2.5 \mathrm{~cm}$ long. Disk annular, slightly 5-lobed. Stamens 5, inserted, unequal, 2 long, 3 short; filaments attached at $c$. $4 \mathrm{~mm}$ above the corolla base, dilated and hairy at base; anthers oblongoid, 1-4 mm long. Pollen grains (Fig. 3a, b) pantoporate, oblate-spherical, $\mathrm{P}$ $=74.12 \mu \mathrm{m}, \mathrm{E}=88.71 \mu \mathrm{m}$, operculum less granulate; pores surrounded by extraspinulose ring-shaped area; exine surface reticulate; tectum with spines in rows and less granules; spines 3-6 $\mu \mathrm{m}$ long, broad and bulbous at base, gradually tapering towards apex with blunt tip forming a distinct constriction at the neck region, basal cushion width $0.85-1.5 \mu \mathrm{m}$; spines and pores arranged in distance 3-6 $\mu \mathrm{m}$; lumina very small; extrapolar area obscure. Ovary conical, c. $1 \mathrm{~mm}$ long, glabrous; style slender, $0.5-2.5 \mathrm{~cm}$ long, inserted; stigma biglobose. Berry depressed-subglobose, $c$. $1 \mathrm{~cm}$ across, red, 2-seeded; fruiting sepals large, coriaceous, slightly subequal, inner 3 broader than outer 2; outer 2 ovate-lanceolate, $6-6.2 \times$ c. $5 \mathrm{~mm}$, retuse to obtuse at apex, sparsely strigose outside; inner 3 orbicular or suborbicular, $5.5-6 \times 6-7.5 \mathrm{~mm}$,
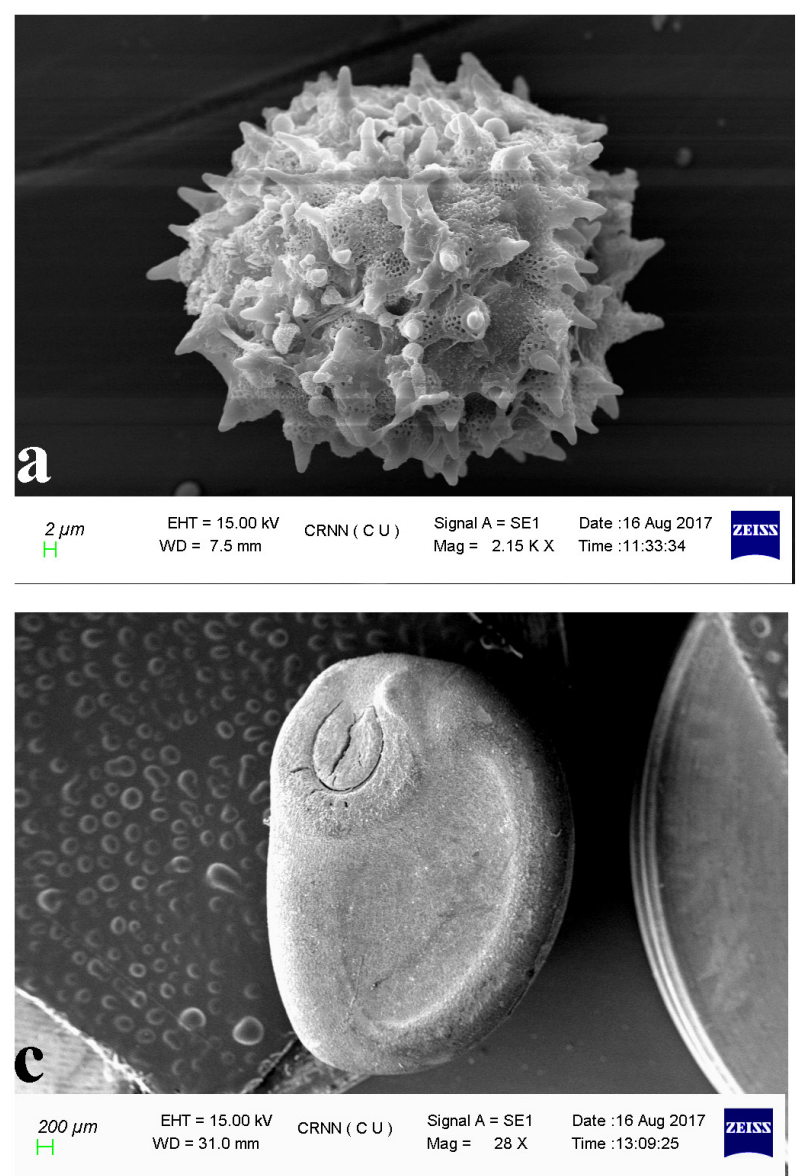
parallel; inter spinal distance 8-13 $\mu \mathrm{m}$; interporal

margins membranous, glabrous on both surfaces. Seeds (Fig. 3c, d) 4, ovoid-trigonous, 5-5.2 × 4-5 $\mathrm{mm}$, glabrous, brown or black on dry; epidermal cells irregular or polygonal with raised, straight and slightly sinuous anticlinal walls; periclinal walls flat, convex with folded outer surface.

Flowering \& fruiting: July-March.

Distribution: India (Manipur) and Myanmar (Fig. 4.)

Specimens examined: INDIA, Manipur: Kaptu, 4-5000 ft, November 1907, A. Meebold 6521 (CAL). MYANMAR, Maymyo, December 1888, D. Khan 303 (CAL); Maymyo, 93 miles from Mandalay, December 1888, Dr. King's Collector, Badulkhan 303 (CAL); Upper Burma, Makhoye hills, 10.03.1893, Dr. King's Collector 344 (CAL); Maymyo, 2000 ft, January 1908, A. Meebold 8039 (CAL); Maymyo Plateau, 3500 ft, 19.07.1908, J.H. Lace 4104 (CAL); Ibid., 3500 ft, 11.10.1908, J.H. Lace 4321 (CAL); Maymo, Peinngon Ywago Road, 3700 ft, 07.12.1924, Mg. Kan 598 (CAL); Maymyo, 08.08.1925, Saw Mong Kya 1769 (DD); Ibid., 02.01.1927, H.G. Champion s.n. (DD).
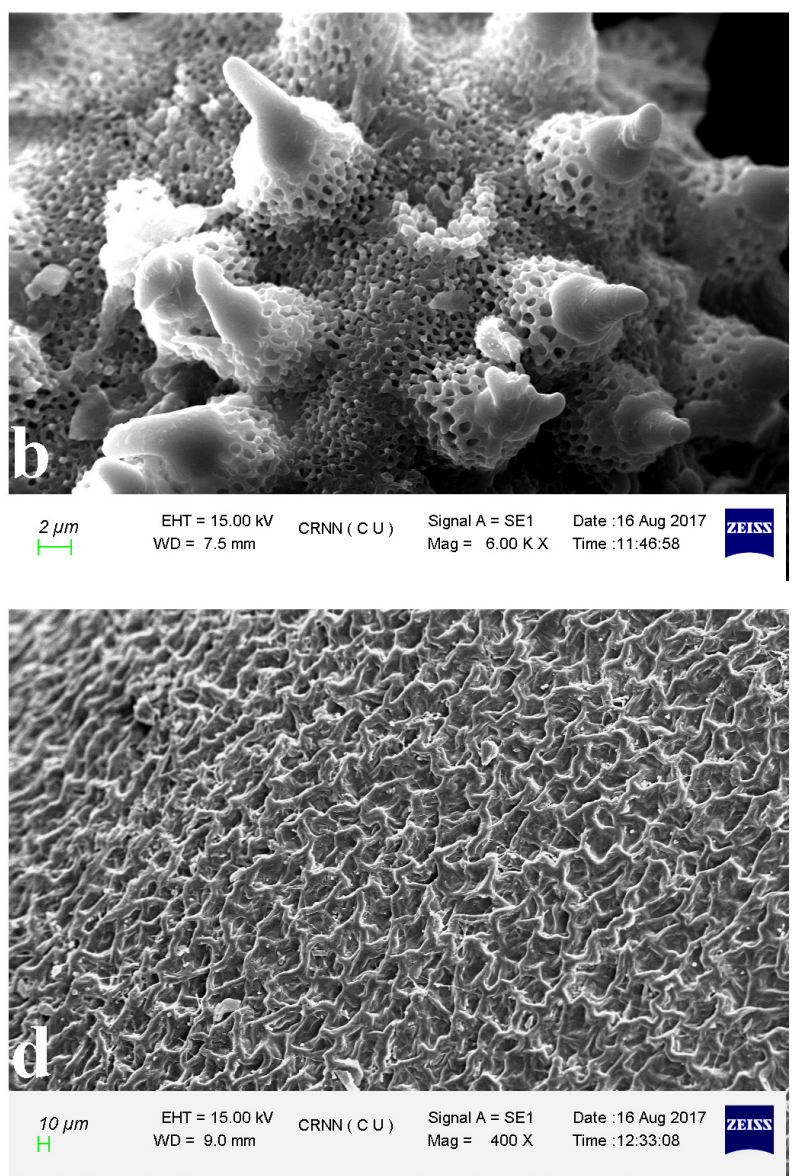

Fig. 3. SEM micrographs of pollen and seed of Argyreia longifolia (Collett \& Hemsl.) Raizada: a. Entire pollen b. A portion of pollen enlarged showing ornamentation; c. Entire seed $\mathbf{d}$. Enlarged view of seed coat. 

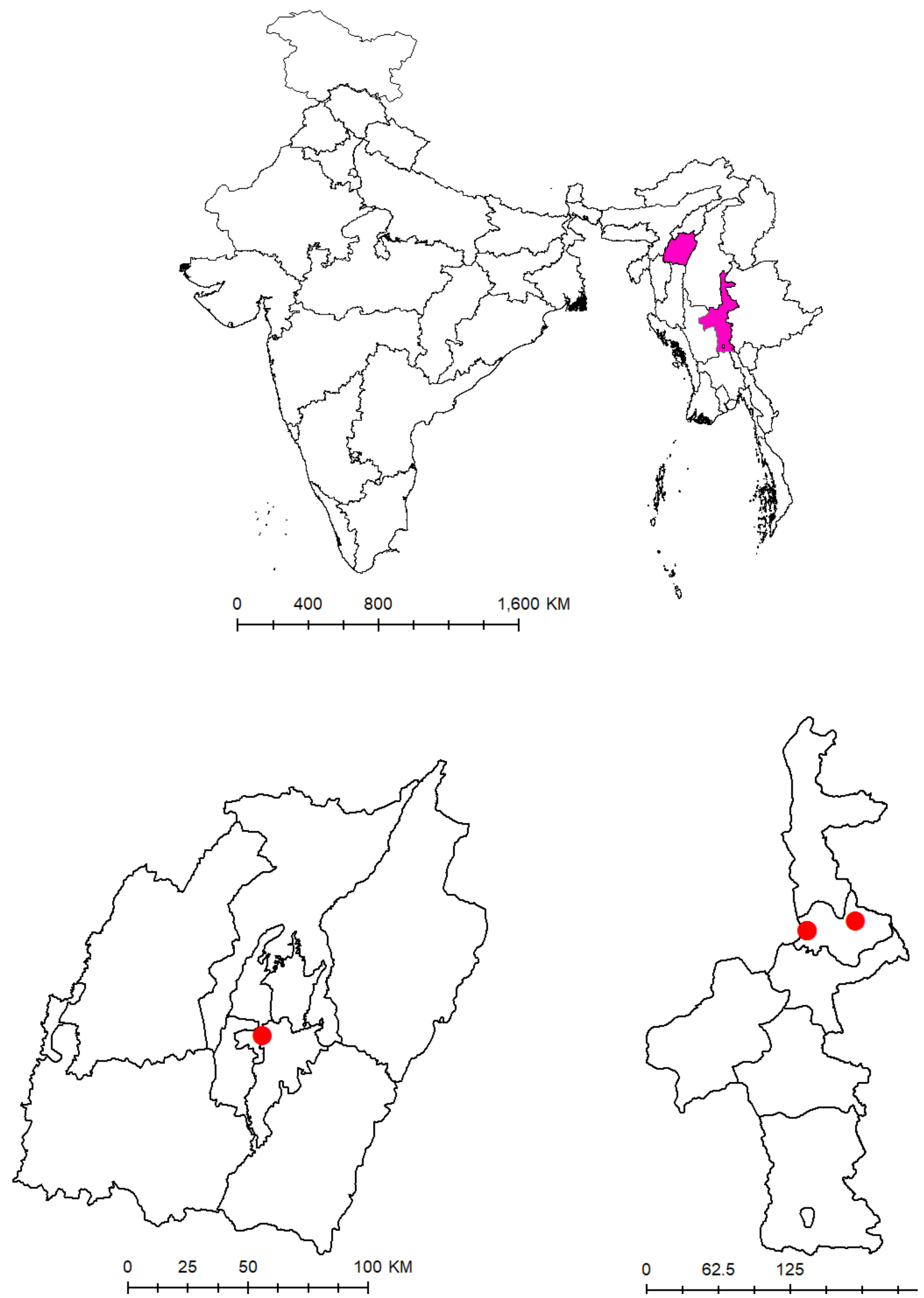

Fig. 4. Distribution of Argyreia longifolia (Collett \& HemsI.) Raizada in India and Myanmar. 


\section{Lectotypification}

The search of type specimen(s) of A. longifolia collected from Shan hill terai, near Pyinyoung in Myanmar resulted in locating two specimens of Collett at K (K000196046) and CAL (CAL0000018540). The sheet at CAL is with a fruiting material, whereas the one at $\mathrm{K}$ contains both flowers and fruits. Moreover, the sheet at K has details such as name of the locality with elevation and date of collection in Collett's handwriting on the original label and the specimen also matches well with the description given in the protologue. Hence, the specimen at $\mathrm{K}$ bearing the barcode, K000196046 (Fig. 2) has been chosen here as the lectotype for the name and the specimen at CAL (CAL0000018540) is considered as isolectotype conforming to the latest code (Turland et al., 2018).

\section{Acknowledgements}

The authors are grateful to Dr. Paramjit Singh, Director, Botanical Survey of India (BSI), Kolkata and Dr. P.V. Prasanna, Scientist 'F' \& Head of Office, Central National Herbarium, BSI, Howrah (CAL), for facilities and encouragement. The authors also thank the Board of Trustees of Royal Botanic Gardens, Kew, for permitting to publish the image of the lectotype. The first author is thankful to Ms. Natasha Srivastava, Junior Project Fellow, CAL, for preparing the map and Mr. D.K. Sah, Artist, CAL, for the line drawing.

\section{Literature Cited}

Bennet, S.S.R. 1987. Name changes in flowering plants of India and Adjacent regions. Triseas Publishers, Dehra Dun.

Clarke, C.B. 1939. Convolvulaceae. In: Kanjilal, U.N., Das, A., Kanjilal, P.C. \& R.N. De (eds.), The Flora of Assam. Vol. 3. Caprifoliaceae to Plantaginaceae. Prabasi Press, Kolkata. pp. 338362.

Collett, C.B. \& W.B. Hemsley 1890. On a collection of plants from upper Burma and the Shan states. J. Linn. Soc., Bot. 28: 1-150.
Hooker, J.D. (ed.) 1872-1897. The Flora of British India. Vols. 1-7. L. Reeve \& Co., London.

Mao, A.A., Sinha, B.K., Verma, D. \& N. Sarma 2016. Checklist of flora of Meghalaya. Meghalaya Biodiversity Board, Shillong.

Naithani, H.B. 1990. Flowering Plants of India, Nepal $\mathcal{E}$ Bhutan (not recorded in Sir J.D. Hooker's Flora of British India). Surya Publications, Dehra Dun.

Prain, D. 1894. Noviciae Indicae 8. Some additional species of Convolvulaceae. J. Asiat. Soc. Bengal 63: 83-115.

Raizada, M.B. 1958. Name changes in common Indian plants. Indian Forester 84(8): 467-538.

Raizada, M.B. 1967. Validating some new combinations relevant to the Flora of India. Indian Forester 93(11): 754-755.

Razi, B.A. 1959. A second list of species and genera of Indian Phanerogams not included in J.D. Hooker's Flora of British India. Rec. Bot. Surv. India 18(1): 1-54.

Staples, G.W. \& P. Traiprem 2017. A nomenclatural review of Argyreia (Convolvulaceae). Taxon 66(2): 445-477.

Turland, N.J., Wiersema, J.H., Barrie, F.R., Greuter, W., Hawksworth, D.L., Herendeen, P.S., Knapp, S., Kusber, W.-H., Li, D.-Z., Marhold, K., May, T.W., McNeill, J., Monro, A.M., Prado, J., Price, M.J. \& G.F. Smith (eds.) 2018. International Code of Nomenclature for algae, fungi, and plants (Shenzhen Code) adopted by the Nineteenth International Botanical Congress Shenzhen, China, July 2017. Regnum Veg. 159. Koeltz Botanical Books, Glashütten. DOI: https://doi.org/10.12705/Code.2018

Received: 07.08.2018

Revised and Accepted: 25.12.2018 